\title{
TRANSFORMASI KEPEMILIKAN DARI SWASTA KE PEMERINTAH: IMPLEMENTASI PELAYANAN PRIMA UNIVERSITAS SILIWANGI KEPADA MAHASISWA
}

\author{
Edi Fitriana Afriza ${ }^{1}$, Syamsudin Arnasik $^{2}$, Yoni Hermawan ${ }^{3}$ \\ ${ }^{1}$ Jurusan Pendidikan Ekonomi, Fakultas FKIP, Universitas Siliwangi \\ Email: edifitriana@unsil.ac.id \\ ${ }^{2}$ Jurusan Pendidikan Ekonomi, Fakultas FKIP, Universitas Siliwangi \\ Email : syamsudinarnasik@unsil.ac.id \\ ${ }^{3}$ Jurusan Pendidikan Ekonomi, Fakultas FKIP, Universitas Siliwangi \\ Email : yonihermawan@unsil.ac.id
}

Masuk : 15-04-2019, revisi: 10-07-2019, diterima untuk diterbitkan : 18-09-2019

\begin{abstract}
ABSTRAK
Menerapkan pelayanan prima menjadi suatu keharusan disetiap lingkungan didalam instansi komersil maupun nonkomersil untuk dapat meningkatkan jiwa kompetitif setiap bagiannya. Sederhananya, pelayanan prima (excellent service) merupakan pelayanan untuk memenuhi standar kualitas yang sesuai dengan harapan dan kepuasan pelanggan. Penelitian ini bertujuan mengetahui implementasi pelayanan prima yang dilaksanakan Universitas Siliwangi dan juga kendala yang dihadapi instansi Universitas Siliwangi dalam merealisasikan pelayanan prima disetiap unit pelayanannya. Metode kualitatif dengan pendekatan fenomenologi digunakan sebagai prosedur dalam acuan dan arahan untuk menyelesaikan penelitian, adapun key informan yang terdiri dari kepala bagian akademik dan kemahasiswaan (1 Orang), karyawan pusat informasi dan pelayanan terpadu (2 Orang), dosen (3 Orang) dan mahasiswa Universitas Siliwangi (4 Orang) akan di interview untuk mendapatkan data-data terkait pelayanan prima. Hasil penelitian yang didapatkan bahwa Universitas Siliwangi sudah melakukan yang terbaik dalam merevitalisasi berbagai layanan kepada mahasiswa, dengan menerapkan standar mutu pelayanan dari Undang-undang pelayanan publik yang baru nomor 25 Tahun 2009 menjadi pedoman berbagai instansi layanan masyarakat. Sedangkan layanan yang harus dilengkapi diantaranya tempat parkir yang masih kurang representatif, staff tenaga kependidikan dilengkapi fasilitas penunjang perangkat komputer serta alur gambar layanan pusat informasi dan pelayanan terpadu (PINTU).
\end{abstract}

Kata Kunci: Pelayanan, Prima, Pendidikan

\section{ABSTRACT}

Implementing excellent service becomes a necessity in every environment in commercial and non-commercial agencies to be able to increase the competitive spirit of each part. Simply put, excellent service (excellent service) is a service to meet quality standards in accordance with customer expectations and satisfaction. This study aims to determine the implementation of excellent service carried out by Siliwangi University and also the obstacles faced by Siliwangi University agencies in realizing excellent service in each service unit. The qualitative method with a phenomenological approach is used as a procedure in referencing and directing to complete research, while key informants consist of heads of academic and student affairs (1 person), information center employees and integrated services (2 people), lecturers (3 people) and students Siliwangi University (4 people) will be interviewed to get data related to excellent service. The results of the study found that Siliwangi University has done its best in revitalizing various services to students, by applying service quality standards from the new Public Service Law number 25 of 2009 to guide various community service agencies. While services that must be completed include a parking lot that is still less representative, educational staff is equipped with supporting facilities for computer equipment as well as an integrated information center and PINTU service flow chart.

Keywords: Service, Prime, Education

\section{PENDAHULUAN \\ Latar Belakang}

Kepuasan konsumen menjadi harapan setiap instansi baik yang bergerak dibidang public service maupun komersil, dimana kepuasan menjadi tolak ukur dalam kesuksesan suatu lembaga dalam melayani konsumennya. Pendidikan merupakan salah satu upaya untuk menciptakan dan menghasilkan anak bangsa yang bermutu. Perguruan tinggi sebagai lembaga formal merupakan 
salah satu lembaga pendidikan yang berupaya untuk menciptakan mutu pendidikan. Dengan melihat situasi dan kondisi sekarang ini, mutu suatu perguruan tinggi dapat terlihat dari kualitas peserta didik dalam hal akademik maupun non akademiknya serta pandangan stigma positif dan negatif yang muncul di masyarakat terhadap perguruan tinggi. Telah menjadi fokus perhatian utama bahwa masih banyak perguruan tinggi kurang responsif dalam pemberian kualitas layanan pada mahasiswa dikarenakan para steakholder, tenaga pendidik dan kependidikan kurang memperhatikan suatu kewajiban akan keharusan pemberian layanan ekstra terhadap mahasiswa. Banyaknya permasalahan yang terjadi dalam layanan bidang akademik maupun non akademik seharusnya dapat dievaluasi dan dijadikan bahan pertimbangan dalam meningkatkan kualitas layanan. Realitas Universitas Siliwangi yang bertransformasi menjadi perguruan tinggi negeri menjadikan layanan prima sebagai penentuan keberhasilan dalam kompetisi persaingan antar perguruan tinggi di masa yang akan datang, diantaranya seperti layanan informasi akademik, layanan kemahasiswaan dan layanan terpadu lainnya akan semakin membantu para mahasiswa dalam menempuh pendidikan di universitas siliwangi.

Senada dari hasil penelitian Khan, Hina dan Matlay, Harry (2009) It is suggested that the involvement of management and staff in implementing service excellence in HEIs could increase staff motivation and retention. all of which would help HEIs gain and maintain a distinctive and sustainable competitive advantage. Akan tetapi ketercapaian tersebut akan mustahil bila seluruh lapisan belum menyadari akan pentingnya layanan prima, maka kesan kualitas perlu dibentuk pada pelanggan ekternal yang nantinya terintegrasi sebagai upaya pemberian layanan prima kepada pelanggan internal. a better understanding of how customers form impressions of quality can provide valuable information to management for designing service delivery systems that enhance customer satisfaction (Seymour, 1992) and for adapting the university environment to the students' needs (Hampton, 1993). Layanan prima memberikan rasa puas dan senang kepada mahasiswa, kepuasan mahasiswa tersebut dapat dijadikan sebagai indikator keberhasilan pelayanan pendidikan. Didukung hasil penelitian (LeBlanc dan Nguyen, 1997) The research shows that reputation, management, faculty and process related variables are important to students in their judgement of quality. The results are encouraging and will lead us to pursue our quest for excellence in education. Seharusnya setiap penyelenggara pelayanan pendidikan secara berkala melakukan survey indeks kepuasan mahasiswa untuk dapat mengontrol dan memperbaiki pelayanan menjadi lebih baik.

Dalam faktanya Universitas Siliwangi belum optimal memberikan layanan kepada mahasiswa, diantaranya terdapat keterbatasan ruang kuliah, area parkir yang kurang memadai serta pengelolaan administrasi akademik yang tidak mengacu pada SOP (Standard Operational Procedure), padahal setiap pemenuhan layanan tersebut di level prodi, fakultas, hingga universitas pasti bertujuan memberikan pemenuhan harapan dan kepuasan mahasiswa. Menindaklanjuti fokus permasalahan tersebut perlunya indikator yang mampu menyelesaikan tujuan penelitian ini, maka untuk mencapainya dengan menerapkan indikator-indikator Undangundang Pelayanan Publik yang baru UU nomor 25 Tahun 2009 yang diantaranya, meliputi kesederhanaan, kejelasan, kepastian waktu, akurasi, kelengkapan sarana prasarana, keamanan, kemudahan akses, dan kenyamanan. Since the late 1970s service quality has been achowledged as a key factor in acquiring and sustaining a competitive advantage (Hampton, 1993). Persaingan yang semakin kompetitif mengharuskan perguruan tinggi untuk selalu meningkatkan kualitas pelayanannya. Sehingga mahasiswa sebagai pelanggan dapat terpuaskan. Service quality can lead to excellence in business education and can have lasting effects on the institution and the students it serves (LeBlanc dan Nguyen, 1997). 
Beredasarkan penjelasan diatas, maka rumusan masalah dalam penelitian ini adalah bagaimana aktualisasi pelayanan prima di lembaga pendidikan tinggi Universitas Siliwangi ditinjau dari delapan (8) standar prosedur pelayanan prima, yaitu: kesederhanaan, kejelasan, ketepatan waktu, akurasi, kelengkapan sarana prasarana, keamanan, kemudahan akses, dan kenyamanan?

\section{METODE PENELITIAN}

Metode kualitatif digunakan dalam penelitian untuk menghasilkan kesimpulan dalam menjawab pertanyaan penelitian. Bogdan dan Taylor (dalam Moleong, 2009) menjelaskan metode kualitatif sebagai prosedur penelitian yang menghasilkan data deskriptif berupa kata-kata tertulis atau lisan dari orang-orang dan perilaku yang dapat diamati. Sedangkan pendekatan fenomenologi dipakai untuk mendapatkan data dari sudut pandang pengalaman subyektif key informan serta peristiwa yang dialaminya. Dari pernyataan Bogdan dan Biklen (dalam Alsa, 2004) peneliti dengan pendekatan fenomenologis berusaha memahami makna dari suatu peristiwa dan saling pengaruhnya dengan manusia dalam situasi tertentu. Dalam mendeskripsikan data yang telah diterima, dilanjutkan dengan menghimpun data yang diperoleh dari hasil penelitian mengenai implementasi pelayanan prima di Universitas Siliwangi Kota Tasikmalaya. Disamping itu Pemilihan key informan dalam penelitian menggunakan teknik purposive sampling, penentuan seorang key informan dipertimbangkan dari peran dan tanggung jawab key informan dalam posisinya saat dilakukan wawancara. Selanjutnya, berdasarkan data atau informasi yang diperoleh dari sampel sebelumnya, Adapun informan dalam penelitian diantaranya, kepala bagian akademik dan kemahasiswaan (1 Orang), karyawan pusat informasi dan pelayanan terpadu (2 Orang), dosen (3 Orang) dan mahasiswa Universitas Siliwangi (4 Orang). Sedangkan untuk teknik pengumpulan data dilakukan dengan observasi partisipasi, wawancara (in-depth interview), dan dokumentasi, selain itu dalam penelitian kualitatif analisis terdiri dari empat alur kegiatan yang terjadi secara bersamaan yaitu pengumpulan data, reduksi data, penyajian data, penarikan kesimpulan/ verifikasi. Untuk menguji keabsahan data maka dilakukan trianggulasi, penggunaan trianggulasi sumber dengan membandingkan dan mengcroschek balik derajat kepercayaan suatu informasi yang diperoleh melalui waktu dan alat yang berbeda dalam penelitian kualitatif, (Ghony \& Almanshur, 2014:323).

\section{HASIL DAN PEMBAHASAN}

Pelayanan prima yang berlangsung merupakan bentuk nyata dalam meningkatkan pelayanan pada dunia pendidikan, diterapkannya layanan tersebut memberikan dampak positif memacu peningkatan kinerja khususnya tenaga kependidikan, dosen dan mahasiswa sebagai subjek dari penerima layanan. Perguruan tinggi negeri Universitas Siliwangi lebih mengutamakan pandangan sebuah nilai dari konsumen (cutomer value), citra (image) dan kepercayaan (trust) yang terbentuk melalui pelayanan prima yang diberikan. Menjadi suatu keharusan bagi Universitas Siliwangi dalam memprioritaskan pelaksanaan pelayanan prima bagi pelanggan internal dan ekternal supaya mampu berkompetisi dengan perguruan tinggi lainnya. "....the university as producer, wholesaler and retailer of knowledge cannot escape service. Knowledge, today is for everybody's sake” (Kerr, 1982:114).

Apalagi kondisi Universitas Siliwangi masih berstatus Perguruan Tinggi Baru (PTNB) yang memerlukan revitalisasi sistem pelayanan terpadu bagi seluruh elemen dari pengguna jasa pendidikan tinggi. Setelah Universitas Siliwangi bertransformasi menjadi perguruan tinggi negeri maka standar pelayanan yang diberikan harus sesuai aturan yang ditetapkan oleh pemerintah, maka dari itu pemerintah menetapkan dan memberlakukan standar mutu pelayanan prima sebagaimana diatur dalam (1) Keputusan Menteri Pendayagunaan Aparatur Negara Nomor 25/KEP/M.PAN/2/2004 Tentang Pedoman Umum Penyusunan Indeks Kepuasan Masyarakat 
Unit Pelayanan Instansi Pemerintah; (2) Keputusan Menteri Negara Pendayagunaan Aparatur Negara (MENPAN) Nomor 63/KEP/M.PAN/7/2003 tentang Pedoman Umum Penyelenggara Pelayanan Publik, dan (3) Undang-undang Pelayanan Publik yang baru UU nomor 25 Tahun 2009. Bahwa implementasi pelayanan prima terkait penelitian yang dilaksanakan pada perguruan tinggi Universitas Siliwangi Kota Tasikmalaya meliputi kesederhanaan, kejelasan, kepastian waktu, akurasi, kelengkapan sarana prasarana, keamanan, kemudahan akses, dan kenyamanan sehingga hasil penelitiannya dapat dilihat sebagai berikut:

a. Kesederhanaan.

Kesederhanaan proses pelayanan akademik menjadikan mahasiswa terlayani dengan prosedur yang telah ditetapkan sesuai Standar Operasional Prosedur (SOP). Kesederhanaan yang dimaksud berkaitan dengan sistem, aturan dan tata cara yang sebelumnya diciptakan secara kompleks serta berbelit-belit diubah menjadi lebih mudah dan praktis supaya mahasiswa dapat menggunakan layanan yang disediakan pihak Universitas Siliwangi.

Hasil wawancara dengan key informan Kepala Bagian Akademik dan Kemahasiswaan berinisial SS ketika ditanya proses kesederhanaan layanan prima Universitas Siliwangi :

"Universitas Siliwangi mengoptimalkan layanan akademik sederhana tanpa mengesampingkan legalitas serta keabsahan kepada mahasiswa, dengan membentuk unit pelaksana pelayanan pusat informasi dan pelayanan terpadu (PINTU) yang terdiri dari pelayanan administrasi keuangan, pelayanan informasi dokumentasi dan UKT, pelayanan sarana dan prasarana, pelayanan akademik (KTM, Cuti \& Mutasi, pelayanan ijazah dan transkrip, pelayanan alumni tracer study, dan pelayanan kemahasiswaan (UKM \& Beasiswa). Dengan kehadiran pusat informasi dan pelayanan terpadu (PINTU) akan terbentuk kesederhanaan dalam pelayanan akademik serta memudahkan mahasiswa dalam segala aktivitas akademiknya, akan tetapi terdapat kekurangan dimana belum terdapat gambar alur pelayanan pusat informasi dan pelayanan terpadu (PINTU) sehingga mahasiswa yang menggunakan pelayanan tersebut mengetahui kesederhanan pelayanan yang diterapkan oleh Universitas Siliwangi." (wawancara, tanggal 2 Agustus 2018)

b. Kejelasan.

Kejelasan informasi berkaitan layanan akademik yang diberikan akan membantu dan mengarahkan mahasiswa, supaya mengikuti alur serta tahapan yang harus dilalui, sehingga terciptannya tujuan setiap pelayanan akademik yang digunakan memenuhi harapan dan waktu yang ditentukan mahasiswa. Universitas Siliwangi menyediakan pelayanan penerima tamu (recepsionist) dalam menujang setiap kegiatan pelayanan untuk mengantisipasi mahasiswa serta masyarakat yang mendapatkan kebingungan pada pelayanan Universitas Siliwangi. Dari hasil wawancara dengan mahasiswa yang berinisial DA diperoleh :

"Bahwa mahasiswa yang memproses terkait keperluan akademik akan diberikan arahan serta dibimbing oleh penerima tamu (recepsionist) secara terperinci. (wawancara, tanggal 6 Agustus 2018)."

Dengan adanya tenaga kerja penerima tamu (recepsionist) akan sangat membantu bagi seluruh pengguna jasa layanan supaya meminimalisir persepsi yang berbeda-beda serta memberikan kejelasan terhadap kewenangan pihak atau unit yang melayaninya kepada siapa, di mana dan kapan, supaya pelanggan mudah apabila terjadi keluhan/ komplain.

c. Ketepatan Waktu.

Ketepatan waktu melayani atau ketika proses pelayanan sedang dilaksanakan sangat diperlukan untuk memberikan pelayanan prima. Tenaga kependidikan pusat informasi dan pelayanan terpadu (PINTU) Universitas Siliwangi cepat serta tanggap dalam memberikan informasi ketepatan waktu pelayanan yang digunakan mahasiswa, semuanya sudah diatur dalam Standar Operasional Prosedur (SOP), adapun berbagai keterlambatan akan segera 
diantisipasi melalui mencari alternatif solusi jika pelayanan yang digunakan bersifat penting serta urgent.

d. Akurasi.

Penyelenggaraan pelayanan prima Universitas Siliwangi melalui pusat informasi dan pelayanan terpadu (PINTU) memegang teguh prinsip akurasi, dimana pelayanan prima sudah tepat sasaran atau akurat, karena tenaga kependidikan sudah melayani apa yang di butuhkan oleh mahasiswa. Dari hasil wawancara yang telah dilakukan dengan mahasiswa yang berinisial SA mengemukakan :

"Bahwa para tenaga kependidikan melaksanakan tugas dan tanggung jawab sesuai prosedur/ SOP dan tuntutan dari mahasiswa dengan tepat. (wawancara, tanggal 8 Agustus 2018)."

Mahasiswa sudah merasakan proses pelayanan prima secara langsung dari perlakuan para tenaga kependidikan kepada mahasiswa yang kooperatif dan meminimalisir berbagai kesalahan prosedur dan mekanisme melalui sosialisasi alur pelayanan pada media elektronik. Tenaga kependidikan pusat informasi dan pelayanan terpadu (PINTU) telah melaksanakan pelayanan prima secara akurat, hal tersebut merupakan wujud upaya Universitas Siliwangi memberikan hak atas pelayanan prima kepada semua mahasiswa. Pelayanan prima secara akurat juga sebagai wujud partisipasi Universitas Siliwangi dalam mewujudkan service excellent di lingkungan pergguruan tinggi.

e. Kelengkapan Sarana dan Prasarana.

Pelayanan prima akan mudah terwujud apabila seluruh unit pelayanan memiliki sarana dan prasarana yang menujang untuk memungkinkan mahasiswa mendapatkan pelayanan berkualitas. Berdasarkan observasi pada Universitas Siliwangi sudah berupaya untuk melengkapi berbagai fasilitas sarana dan prasarana penunjang pelayanan prima akan tetapi masih terbatasnya fasilitas seperti perangkat komputer untuk tenaga kependidikan dan tempat parkir khusus mahasiswa, dosen, dan tenaga kependidikan, dikarenakan Universitas Siliwangi masih dalam kondisi transisi dari PTS menjadi PTN. Kurangnya perangkat komputer pada unit layanan akan menimbulkan hambatan dalam memberikan layanan prima, apalagi belum tersedianya tempat parkir menjadikan mahasiswa kesulitan untuk menempatkan kendaraanya, sehingga memunculkan persepsi dan citra yang kurang baik bagi Universitas Siliwangi. Adapun hasil observasi lapangan dalam meninjau sarana dan prasarana sebagai adalah sebagai berikut:

Tabel 1 - Hasil Observasi Ketersediaan Sarana dan Prasarana Sumber: Hasil Observasi Tanggal 8 Agustus 2018

\begin{tabular}{|c|c|c|c|c|c|}
\hline No. & Sarana dan Prasarana & Baik & Cukup & Kurang & Keterangan \\
\hline 1. & $\begin{array}{l}\text { Ruang tunggu yang } \\
\text { nyaman, luas dan } \\
\text { lengkap }\end{array}$ & $\sqrt{ }$ & & & $\begin{array}{l}\text { Ruang tunggu yang } \\
\text { luas dengan kapasitas } \\
\text { dapat menampung } 20 \\
\text { orang }\end{array}$ \\
\hline 2. & Buku tamu yang lengkap & $\sqrt{ }$ & & & $\begin{array}{l}\text { Recepsionist } \\
\text { menerima tamu dan } \\
\text { melakukan pendataan } \\
\text { terhadap tamu }\end{array}$ \\
\hline 3. & $\begin{array}{l}\text { Perangkat komputer } \\
\text { untuk membantu } \\
\text { pelayanan }\end{array}$ & & & $\sqrt{ }$ & $\begin{array}{l}\text { Belum lengkapnya } \\
\text { perangkat komputer } \\
\text { pada setiap unit } \\
\text { pelayanannya }\end{array}$ \\
\hline 4. & Bandwith untuk akses & $\sqrt{ }$ & & & Bandwidth komersial \\
\hline
\end{tabular}




\begin{tabular}{|c|l|l|l|l|l|}
\hline internet & & & $\begin{array}{l}\text { dengan kapasitas } \\
\text { hingga mencapai 150 } \\
\text { Mbps }\end{array}$ \\
\hline 6. & $\begin{array}{l}\text { Ruang kuliah dan } \\
\text { laboratorium dilengkapi } \\
\text { Proyektor dan ber-AC }\end{array}$ & $\sqrt{ }$ & $\begin{array}{l}\text { Puang kuliah yang } \\
\text { memadai dilengkapi } \\
\text { dengan proyektor dan } \\
\text { AC }\end{array}$ \\
\hline 7. & $\begin{array}{l}\text { Kamera CCTV di untuk } \\
\text { keamanan }\end{array}$ & $\sqrt{ }$ & & $\begin{array}{l}\text { Perpustakaan yang } \\
\text { recomended denga } \\
\text { buku yang lengkap }\end{array}$ \\
\hline 8. & $\begin{array}{l}\text { Tempat parkir kendaraan } \\
\text { luas, aman dan nyaman }\end{array}$ & & $\begin{array}{l}\text { Kamera keamanan } \\
\text { CCT di pasang pada } \\
\text { area strategis }\end{array}$ \\
\hline
\end{tabular}

Diperkuat memalui pandangan tenaga kependidikan berkaitan sarana dan prasarana berinisial $\mathrm{HN}$ menyatakan bahwa. Masih terdapat kekurangan dari jumlah perangkat komputer yang dipakai para tenaga kependidikan sehingga mengakibatkan pelayanan belum optimal. Beberapa tenaga kependidikan masih memanfaatkan perangkat komputer yang ada. (wawancara, tanggal 2 Agustus 2018).

f. Keamanan.

Keamanan merupakan jaminan rasa aman atau sikap dapat dipercaya yang diberikan Universitas Siliwangi untuk melindungi mahasiswa dalam proses pelayanan. Jaminan yang diberikan Universitas Siliwangi merupakan hal penting bagi kepuasan pelanggan. Semakin tinggi jaminan yang diperlihatkan Universitas Siliwangi melalui tenaga kependidikan maka mahasiswa akan merasakan pelayanan prima yang diterima. Kabag. Akademik dan Kemahasiswaan berinisial SS menanggapi pertanyaan yang diajukan sebagai berikut:

"Data yang ditampilkan di sistem informasi merupakan data konsumsi warga Universitas Siliwangi, sedangkan setiap data pribadi mahasiswa hanya yang bersangkutan yang dapat mengetahuinya, karena setiap mahasiswa akan diberikan username dengan pasword yang berbeda untuk mengakses layanan sitem informasi akademik. (wawancara, tanggal 2 Agustus 2018)."

Sistem informasi akademik yang dirancang untuk melayani aktivitas akademik mahasiswa diberikan sistem keamanan untuk mencegah data-data yang sifatnya bukan konsumsi publik dapat terjaga kerahasiannya. Seluruh mahasiswa dan dosen diberikan username serta pasword yang berbeda dan hanya yang bersangkutan yang dapat mengakses sistem informasi akademik demi keamanan civitas akademika.

g. Kemudahan Akses.

Kemudahan mengakses lokasi perguruan tinggi merupakan indikator penting bagi terselenggaranya pelayanan prima, masyarakat akan cepat mengetahui Universitas Siliwangi dikarenakan lokasinya yang strategi dekat dengan pusat perkotaan dan mudah diakses melalui alat transportasi umum ataupun berjalan kaki. Didukung dari hasil wawancara dengan salah satu mahasiswa yang berinisial RY sebagai berikut: 
"Menemukan lokasi Universitas Siliwangi sangatlah mudah, dengan adanya mesin pencarian secara online memudahkan mahasiswa dan masyarakat yang belum pernah mengunjungi Universitas Siliwangi. (wawancara, tanggal 8 Agustus 2018)."

Masyarakat tidak akan dibuat bingung dan kesulitan untuk menemukan lokasi lembaga pendidikan tinggi Universitas Siliwangi, dengan bantuan akses online sehingga dapat mudah ditemukannya lokasi tersebut.

h. Kenyamanan.

Kondisi nyaman sangat diharapkan oleh setiap pelanggan yang memakai jasa layanan, terutama mahasiswa sebagai pelanggan eksternal Universitas Siliwangi mendambakan berbagai kenyamanan dari fasilitas yang disediakan, selain itu kenyaman para tenaga kependidikan dalam memperlakukan mahasiswa sebagai ujung tombak penyedia jasa pendidikan. Berdasarkan hasil wawancara dengan mahasiswa yang berinisial RH sebagai berikut:

"Setelah berstatus negeri, Universitas Siliwangi memperbaharui dan menyediakan fasilitas yang bersih nyaman agar terciptanya kepuasan pada mahasiswa sebagai pengguna jasa pendidikan. Misalnya ruang kuliah setiap harinya dibersihkan serta dirapihkan, peralatan laboratorium mulai dilengkapi, perpustakaan melengkapi berbagai sarana penunjang sumber literasi dan toilet yang bersih dan nyaman. (wawancara, tanggal 6 Agustus 2018)." Universitas Siliwangi menyediakan berbagai fasilitas diantaranya ruang tunggu pusat informasi dan pelayanan terpadu (PINTU) serta terdapat juga fasilitas pendukung seperti ruang kuliah, perpustakaan, laboratorium dan toilet dalam menunjang pelayanan prima. Akan tetapi masih terdapat fasilitas yang belum memadai dalam menunjang pelayanan prima Universitas Siliwangi terutama kursi dan meja kantor bagi tenaga pendidik, tempat ibadah yang masih dalam proses perbaikan dan juga tempat parkir yang kurang representatif mengakibatkan adanya layanan prima yang kurang optimal diberikan Universitas Siliwangi.

Berdasarkan hasil penelitian yang dilakukan, dapat diketahui faktor-faktor yang menjadi kendala dalam pelayanan prima di lembaga pendidikan tinggi Universitas Siliwangi adalah sebagai berikut:

1. Beberapa kendala yang dihadapi Universitas Siliwangi dalam memberikan pelayanan prima kepada mahasiswa diantaranya sarana dan prasarana yang kurang memadai dalam menujang pelaksanaan pelayanan prima. Dengan status Universitas Siliwangi yang masih tergolong baru sebagai Perguruan Tinggi Negeri Baru (PTNB) menjadi suatu awal perubahan birokrasi administrasi yang tadinya perguruan tinggi swasta menjadi perguruan tinggi negeri, masa transisi yang akan memakan waktu cukup lama jikalau semua elemen internal didalamnya tidak menghendaki revitalisasi pelayanan terhadap mahasiswa sebagai pelanggan eksternal. Sarana dan prasarana yang dimiliki Universitas Siliwangi juga perlu ditingkatkan dengan dukungan anggaran dari pemerintah sudah seharusnya Universitas Siliwangi menyediakan secara lengkap dan menyeluruh fasilitas utama maupun pendukung bagi aktivitas mahasiswa, akan tetapi semuanya memerlukan proses secara bertahap (continue). Belum tersedinya lokasi parkir yang dapat menampung kendaraan baik roda dua maupun empat, mengakibatkan kebanyakan mahasiswa memparkirkan kendraraanya sembarangan, selain itu beberapa unit layanan yang setiap harinya melayani mahasiswa belum dilengkapi dengan perangkat komputer untuk membantu menyederhanakan pelayanan.

2. Kendala yang lainnya terdapat pada prinsip melayani tenaga kependidikan Universitas Siliwangi, dimana para tenaga kependidikan Universitas Siliwangi masih belum optimal dalam melayani mahasiswa, sikap setengah hati tenaga kependidikan ditunjukkan kepada 
mahasiswa diantaranya rendahnya sikap disiplin para tenaga kependidikan dalam berpakaian, kurangnya sikap ramah, responsif dan kooperatif dalam pelayanan serta para tenaga kependidikan masih banyak belum menujukkan totalitas dalam bekerja. Budaya bekerja tersebut disebabkan adanya pengaruh dari kebiasaan tenaga kependidikan Univeritas Siliwangi masih berstatus perguruan tinggi swasta, kebiasaan yang dilakukan tidak sepantasnya masih berlaku di perguruan tinggi negeri, dikarenakan dapat menghambat proses pelayanan akademik terhadap mahasiswa. Maka dari itu sangat diperlukan adanya revitalisasi budaya kerja tenaga kependidikan Universitas Siliwangi dalam meningkatkan pelayanan dan terciptanya pelayanan prima kepada mahasiswa.

\section{KESIMPULAN DAN SARAN}

Berdasarkan hasil penelitian yang telah dilakukan pada aktualisasi pelayanan prima di lembaga pendidikan tinggi Universitas Siliwangi dapat diketahui dari delapan (8) standar prosedur pelayanan prima yaitu kesederhanaan, kejelasan, ketepatan waktu, akurasi, kelengkapan sarana prasarana, keamanan, kemudahan akses, dan kenyamanan yang dapat dijabarkan sebagai berikut:

a. Pelaksanaan pelayanan prima di Universitas Siliwangi ditinjau dari kesederhanaan prosedur pelayanan, tenaga kependidikan berusaha mengoptimalkan layanan akademik yang sebelumnya berjalan secara kompleks, berbelit-belit serta memakan waktu lama dapat disederhanakan, melalui pusat informasi dan pelayanan terpadu (PINTU) sehingga layanan akademik terhadap mahasiswa berjalan dengan mudah serta efisien memacu peningkatan kepuasan mahasiswa pada layanan Universitas Siliwangi, akan tetapi masih teradapat kekurangan, dimana belum terdapatnya gambar alur pelayanan yang ditempatkan di dekat ruang pusat informasi dan pelayanan terpadu (PINTU).

b. Pelayanan prima ditinjau dari kejelasan, tenaga kependidikan berupaya memberikan informasi berkaitan layanan akademik secara jelas serta detail sehingga mahasiswa merasa terbantu dengan adanya penjelasan secara langsung supaya menghindari persepsi yang multitafsir serta memberikan kejelasan terhadap kewenangan pihak atau unit yang melayaninya.

c. Pelayanan prima dilihat dari ketepatan waktu, para tenaga kependidikan pusat informasi dan pelayanan terpadu (PINTU) Universitas Siliwangi sudah melaksanakan pelayanan yang cepat serta responsif dan memberikan ketepatan waktu kepada mahasiswa supaya pelayanan akademik sesuai dengan waktu yang ditentukan dalam standar operasional prosedur (SOP).

d. Penyelenggaraan pelayanan prima Universitas Siliwangi menitiberatkan akurasi pada layanan akademiknya, tenaga kependidikan pusat informasi dan pelayanan terpadu (PINTU) memberikan pelayanan yang tepat sasaran dan akurat sebagai wujud dari upaya Universitas Siliwangi memberikan hak atas pelayanan prima kepada semua mahasiswa.

e. Kelengkapan sarana dan prasarana dalam mewujudkan pelayanan prima Universitas Siliwangi pada mahasiswa, menyediakan sarana serta prasarana yang lengkap untuk menujang setiap unit layanan merupakan keharusan lembaga pendidikan, dengan ditunjang sarana serta prasarana berbagai aktivitas akan mengalami kemudahan dan kelancaran, Universitas Siliwangi masih memiliki kekurangan dalam melengkapi sarana dan prasarana diantaranya area parkir terbatas dan perangkat komputer kurang reprsentatif dengan jumlah unit layanan yang tersedia mengakibatkan pelaksanaan pelayanan prima masih belum maksimal.

f. Jaminan rasa aman atau sikap dapat dipercaya yang diberikan Universitas Siliwangi dalam proses pelayanan merupakan indikator utama dalam melaksanakan pelayanan prima pada lembaga pendidikan tinggi serta sifat tenaga kependidikan yang dapat dipercaya tersebut bisa mendukung proses pelayanan yang prima kepada mahasiswa. Sistem informasi 
akademik dirancang untuk melayani aktivitas akademik mahasiswa dengan komponen keamanan dalam menyimpan data-data dari mahasiswa.

g. Pelaksanaan pelayanan prima di lembaga pendidikan tinggi Universitas Siliwangi ditinjau dari kemudahan akses, yang berada di pusat kota menjadikan mudah untuk diakses menggunakan kendaraan maupun pejalan kaki. Sedangkan untuk lokasi Universitas Siliwangi, masyarakat mudah menemukannya dengan melalui cara mengakses secara online.

h. Kenyamanan yang menjadi ekspektasi mahasiswa terhadap pelayanan prima yang diberikan Universitas Siliwangi, terutama pelayanan pusat informasi dan pelayanan terpadu (PINTU) yang sudah terbukti melayani secara progres kearah yang lebih baik, akan tetapi beberapa kekurangan yang diantaranya ditemukan pada kondisi area parkir yang terbatas menjadi hambatan bagi optimalnya pelaksanaan pelayanan prima kepada mahasiswa sehingga sulit terciptannya keunggulan kompetitif.

\section{REFERENSI}

Alsa, Asmadi. (2004). Pendekatan Kualitatif dan Kuantitatif serta Kombinasinya dalam penelitian Psikologi. Yogjakarta: Pustaka Pelajar

Hampton, G. M. (1993). Gap Analysis of College Student Satisfaction as a Measure of Professional Service Quality. Journal of Professional Services Marketing, 9(1), 115-128. https://doi.org/10.1300/J090v09n01_10

Keer, Clark, (1982), The Uses of The University, Harvard University Press, Cambridge, Massachusetts.

Khan, Hina, and Harry Matlay. (2009). "Implementing Service Excellence in Higher Education."Education+Training51(8/9):769-80.

http://www.emeraldinsight.com/doi/10.1108/00400910911005299.

LeBlanc, G., \& Nguyen, N. (1997). Searching for excellence in business education: an exploratory study of customer impressions of service quality. International Journal of Educational Management, 11(2), 72-79. https://doi.org/10.1108/09513549710163961

Malik, M. E., Danish, R. Q., \& Usman, A. (2010). The impact of service quality on students' satisfaction in higher education Institutes of Punjab. Journal of Management Research, 2(2), 1-11. https://doi.org/10.5296/jmr.v2i2.418

McCowan, T. (2018). Quality of higher education in Kenya: Addressing the conundrum. International Journal of Educational Development, 60 (November 2017), 128-137. https://doi.org/10.1016/j.ijedudev.2017.11.002

Menteri Pendayagunaan Aparatur Negara RI. Keputusan Menteri Pendayagunaan Aparatur Negara Nomor: 63/KEP/M.PAN/7/2003. Tentang Pedoman Umum Penyelenggaraan Pelayanan Publik.

Menteri Pendayagunaan Aparatur Negara RI. Keputusan Menteri Pendayagunaan Aparatur Negara Nomor: KEP/26/M.PAN/2/2004 tentang Petunjuk Teknis Transparansi dan Akuntabilitas dalam Penyelenggaraan Pelayanan Publik.

Miles, B. Mathew dan Michael Huberman. (1992). Analisis Data Kualitatif Buku Sumber Tentang Metode-metode Baru. Jakarta: UIP.

Moleong, J Lexy, (2009). Metode Penelitian Kualitatif. Bandung: PT. Remaja Rosdakaya

Rahmayanty, Nina. (2010). Manajemen Pelayanan Prima. Yogyakarta: Graha Ilmu.

Republik Indonesia. Undang-Undang Republik Indonesia Nomor 25 Tahun 2009 tentang Pelayanan Publik.

Seymour, D.T. (1992), On Q: Causing Quality in Higher Education, Macmillan Press, New York, NY. 
Sinambela, Lijan Poltak. Dkk. (2011) .Reformasi Pelayanan Publik. Jakarta: Bumi Aksara.

Sugiyono. (2009). Metode Penelitian Bisnis (Pendekatan Kuantitatif, Kualitatif, dan R\&D). Bandung: Alfabeta.

Windasuri dan Susanti. (2017). Excellent Service: The Secrets Of Building a Service Organization. Jakarta: Gramedia Pustaka Utama. 